ISSN : 2550-0198

\title{
PELATIHAN KEWIRAUSAHAAN "MENUMBUHKAN JIWA PEMUDA YANG BERKARAKTER ENTREPRENEUR” DI SMA NEGERI 1 HULU KUANTAN KABUPATEN KUANTAN SINGINGI
}

\author{
Dedi Dermawan*, Satriardi, Zayyinul Hayati Zen, Denny Astrie Anggraini, \\ St.Nova Meirizha, Faradila Ananda Yul \\ Program Studi Teknik Industri, Fakultas Teknik \\ email: dedi@umri.ac.id
}

\begin{abstract}
Entrepreneurial ability is the basic capital for someone who wants to move in a particular business field. There are some people who believe that entrepreneurial ability is a gift that is born from birth, this opinion is wrong. Entrepreneurial ability is not due to talent factors, but also arises and feels through entrepreneurial experiences and training. The importance of understanding the world is important to the people in Kuantan Singingi district, in order to empower human resources to be able to manage the huge potential of natural resources. That can be done, among others, by providing training to students, this is done because the introduction of entrepreneurship must be learned and instilled from a young age. In this regard, Industrial Engineering study program at the University of Muhammadiyah Riau opens opportunities for students who want to develop and develop their entrepreneurial spirit to get Knowledge and plan a business. This was applied to community service with the Entrepreneurship Training "Growing the Soul of Youth with Entrepreneurial Characteristics" in Hulu Kuantan 1 Public High School, Kuantan Singingi District.
\end{abstract}

Keywords: Entrepreneurship Training, character and creativity

\begin{abstract}
Abstrak
Kemampuan wirausaha merupakan modal dasar bagi seseorang yang ingin bergerak di bidang usaha tertentu. Ada sebagian orang yang percaya bahwa kemampuan wirausaha adalah bakat yang dibawa sejak lahir, Pendapat ini keliru. Kemampuan wirausaha bukanlah karena faktor bakat, tetapi juga akan timbul dan terasa melalui pengalaman-pengalaman dan pelatihan-pelatihan kewirausahaan. Pentingnya pemahaman akan dunia usahadirasakan penting bagi masyarakat di kabupaten Kuantan Singingi, guna memberdayakan sumber daya manusia untuk bisa mengelola potensi sumber daya alam yang besar. Hal itu itu dapat dilakukan diantaranya dengan cara memberikan pelatihan kepada siswa/i, hal ini dilakukan karena pengenalan kewirausahaan ini harus diketahaui dan ditanamkan mulai usia muda. Berkaitan dengan hal ini prodi Teknik Industri Universitas Muhammadiyah Riau membuka kesempatan kepada Siswa yang ingin membangun dan mengembangkan jiwa wirausahanya untukmendapatkan Pengetahuan dan merencanakan sebuah usaha. Hal ini diaplikasikan pada pengabdian kepada masyarakat dengan Pelatihan Kewirausahaan "Menumbuhkan Jiwa Pemuda Yang Berkarakter Entrepreneur" di SMA Negeri 1 Hulu Kuantan Kabupaten Kuantan Singingi
\end{abstract}

Kata Kunci: Pelatihan Kewirausahaan, berkarakter dan kreatif 


\section{PENDAHULUAN}

Menurut Mudrajad Kuncoro (2008) mengemukakan bahwa UMKM terbukti tahan terhadap krisis dan mampu survive dalam perekonomian Indonesia pada periode krisis tersebut. Serapan tenaga kerja sektor UMKM di Riau berdasarkan data resmi keberadaan UMKM di Riau hingga akhir 2009 sebanyak 470.000 unit. Berdasarkan standar nasional, setiap UMKM di Indonesia rata-rata menjadi tempat pekerjaan bagi dua orang. Jadi dapat disimpulan bahwa sektor usaha UMKM telah menjadi bukti nyata, dan telah dapat menjadi basis kekuatan serta ketahanan ekonomi Indonesia, sampai dengan data tahun 2007 sektor usaha UMKM telah memberikan kontribusi bagi perekonomian Indonesia sebagai berikut : (1). Mencapai jumlah unit usaha 48,9 juta unit usaha atau sekitar 99,98 persen terhadap total unit usaha di Indonesia pada tahun 2006, (2). Daya serap tenaga kerja, sektor UMKM mampu menyerap tenaga kerja 85,4 juta orang atau 96,18 \% dari total angkatan kerja Indonesia. (3). Memberikan kontribusi sebesar Rp 122,2 trilyun atau $20,1 \%$ terhadap total ekspor non migas nasional. (4). Mencapai jumlah unit usaha 50,70 juta unit usaha atau 98,9\% terhadap total unit usaha di Indonesia pada tahun 2007. (5). Memberikan kontribusi terhadap PDB Indonesia sebesar 1.7878,7 triliyun atau sebesar $53,3 \%$ dari total PDB Indonesia.

Potensi sumber daya alam Kabupaten Kuantan Singingi memiliki banyak peluang usaha untuk dapat dikembangakan. Maka dari itu diperlukan agen penggerak perubahan di negeri ini yang akan memegang estafet kepemimpinan di masa mendatang harus berperan aktif untuk menjadi pelopor terbentuknya perekonomian nasional yang tangguh untuk bisa mengelola potensi sumber daya alam yang besar. Hal itu itu dapat dilakukan diantaranya dengan cara memberikan pelatihan kepada siswa/i, dengan memperkenalkan dan menginformasikan bidang wirausaha sehingga kewirausahaan ini harus diketahaui dan ditanamkan mulai usia muda.

Oleh karena itu sudah saatnya dilakukan perubahan paradigma berpikir dikalangan Siswa. Yaitu dari pola pikir sempit mencari kerja setelah lulus kuliah menjadi pencipta lapangan kerja yang berbasis pada penciptaan usaha kecil dan menengah, sehingga berkarakter wirausaha dalam melihat peluangpeluang berwirausaha.

Untuk itu dibutuhkan pengetahuan dan kemampuan wirausaha yang dirintis sejak dari bangku sekolah sehingga kemampuan wirausaha merupakan modal dasar bagi seseorang yang ingin bergerak di bidang usaha tertentu. Kemampuan wirausaha bukanlah karena faktor bakat, tetapi juga akan timbul dan terasa melalui pengalaman-pengalaman dan pelatihan-pelatihan kewirausahaan. Berkaitan dengan hal ini prodi Teknik Industri Universitas Muhammadiyah Riau, membuka kesempatan kepada Siswa yang ingin membangun dan mengembangkan jiwa wirausahanya untuk mendapatkan Pengetahuan dan merencanakan sebuah usaha. Hal ini diaplikasikan pada pengabdian kepada masyarakat dengan pelatihan kewirausahaan "Membangun Wirausaha yang Kreatif dan Inovatif di Usia Muda" di SMA Negeri 1 Hulu Kuantan kabupaten Kuantan Singingi Prov. Riau

\section{METODE PENGABDIAN}

Metode yang digunakan dalam pelaksanaan pengabdian adalah metode pelatihan atau seminar dengan beberapa materi terkait yaitu Pengenalan Kewirausahaan, Motivasi berwirausaha, Inovasi berwirausaha, Peluang 
wirausaha, Inspirasi Wirausaha dan dan diakhiri dengan diskusi anatar peserta.

\section{HASIL DAN PEMBAHASAN}

Kegiatan pengabdian kepada masyarakat dengan pokok materi pengenalan usaha hingga perencanan bisnis untuk memulai usaha. Disini peserta diberikan teori pengenalan usaha, perencanaan untuk memulai usaha, contoh penerepan usaha hingga kerangka perencanaan usaha dalam bentuk bussines plan. Pelaksanaan pengabdian ini dilakukan dalam bentuk penyuluhan, Tanya jawab, diskusi hingga penyelesaian kasus. Diharapkan pelatihan ini dapat memberikan manfaat serta bekal nantinya ketika akan memulai sebuah usaha dimasyarakat.

Untuk mengetahui pencapaian tujuan kegiatan dilakukan evaluasi. Metode evaluasi yang dilakukan adalah dengan mengamati hasil pelatihan yang didapat, yaitu peserta terlihat sangat antusias dan berdiskusi aktif untuk mengetahui dan memahami usaha yang akan direncanakan untuk dikembangkan nantinya. Diharapkan agar kegiatan pelatihan ini terus diadakan karena sangat dirasakan manfaatnya untuk meningkatkan jiwa dan jumlah usaha yang ada dimasyarakat khusunya yang ada di kabupaten Siak. Pendampingan akan terus dilakukan setelah kegiatan pelatihan ini. Tim pelaksana dari Program Studi Teknik Industri akan selalu siap membimbing dan mengarahkan kepada peserta untuk pengembangan usaha atau berwirausaha.

Kegiatan pengabdian kepada masyarakat dengan pokok materi pengenalan wirausaha hingga perencanan bisnis untuk memulai usaha. Disini peserta diberikan teori pengenalan usaha, perencanaan untuk memulai usaha, contoh penerepan usaha hingga kerangka perencanaan usaha dalam bentuk bussiness plan.
Pelaksanaan pengabdian ini dilakukan dalam bentuk penyuluhan, Tanya jawab, diskusi hingga penyelesaian kasus. Diharapkan pelatihan ini dapat memberikan manfaat serta bekal nantinya ketika akan memulai sebuah usaha dimasyarakat.

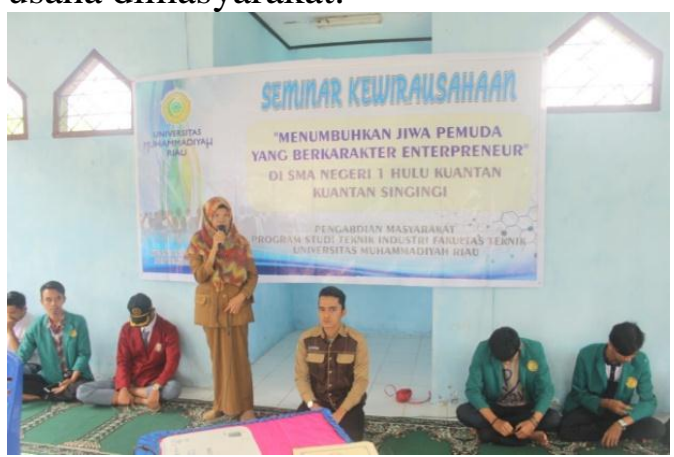

Gambar 1. Kegiatan Pembukaan Pengabdian di SMAN 1 Hulu Kuantan

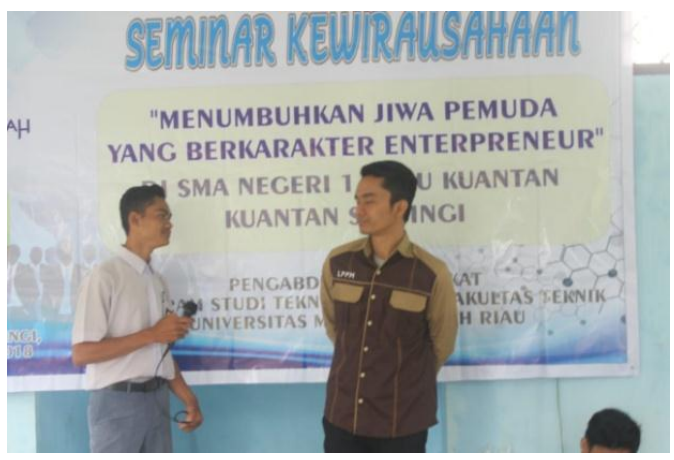

Gambar 2. Sesi Diskusi dengan peserta

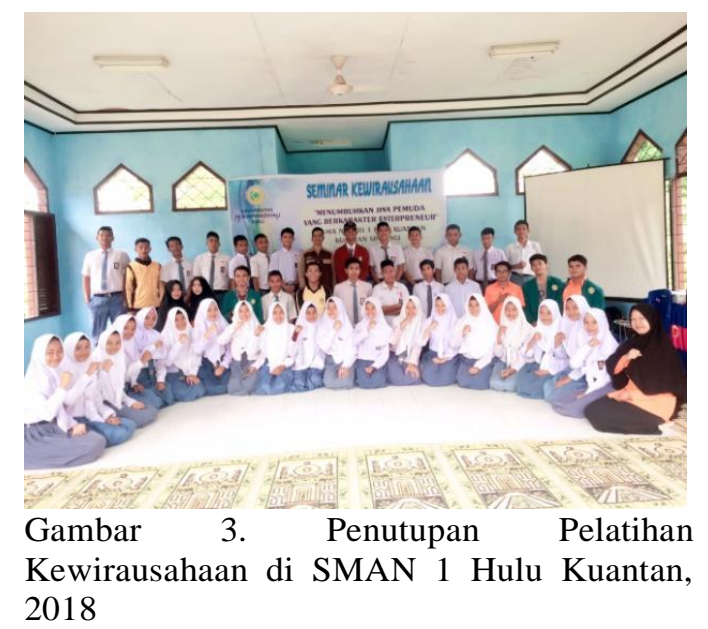

\section{SIMPULAN}

Berdasarkan hasil pelaksanaan kegiatan pengabdian kepada masyarakat ini dan uraian pembahasan di atas, dapat 
disimpulkan beberapa hal sebagai berikut ini.

Pelatihan ini memberikan beberapa materi yang terkait dengan upaya meningkatkan pengetahuan dan wawasan terhadap wirausaha, meningkatkan motivasi untuk bisa menciptakan sebuah usaha sebagai sumber meningkatkan perekonomian keluarga, masyarakat.

Materi yang disajikan dapat diterima, dicerna, dan dipahami peserta dengan baik.

Kegiatan berlangsung lancar, tepat waktu dan sesuai dengan yang diharapkan dan para peserta dapat berkomunikasi dengan para pembicara dan peserta lain dengan baik. Antusias peserta sangat baik, sehingga beberapa peserta sudah merencanakan membuka usaha nantinya.

\section{UCAPAN TERIMAKASIH}

Ucapan terimakasih kami sampaikan kepada Lembaga Penelitian dan Pengabdian Masyarakat Universitas Muhammadiyah Riau sebagai pemberi dana dalam kegiatan pengabdian kepada masyarakat yang telah dilaksanakan pada bulan 03 s/d 04 September 2018 di SMA Negeri 1 Hulu Kuantan, Kabupaten Kuansing Serta ucapan terimakasih kami ucapkan kepada Kepala Sekolah beserta guru dan mahasiswa/i SMA Negeri 1 Hulu Kuantan, Kabupaten Kuansing yang sudah memfasilitasi segala sesuatunya sehingga kegiatan ini berjalan dengan lancar dan sukses.

\section{DAFTAR PUSTAKA}

[1] Almar, Buchori, 2001, kewirausahaan, Bandung, Alfabeta.

[2] Alwisol, 2004, Psikologi Kepribadian, Malang : UMM Press.
[3] Anderson, J,S,. Manz, C,C, \& Prussia, G,E, 1998, Self-leadership and performance outcomes: the mediating influence of self efficacy, Journal of Organizational Behavior, 19, 523-538.

[4] Azwar, S., 1999, Penyusunan Skala Psikologi, Yogyakarta: Pustaka Pelajar.

[5] Hadi, Sutrisno. 1994. Statistik. Yogyakarta : Andi.

[6] Lupiyodi, Rambat, 1998, Wawasan kewirausahaan , Jakarta, Lembaga Penerbit FE-UI

[7] Meredith, G. Goffrey, 1996, Kewirausahaan: Teori dan praktis, Jakarta, Pustaka Binaman Pressindo

[8] Nasution H.A. Bustanul A.N Mukhammad S., 2001, Membangun Spirit Entrepreneur Muda Indonesia, Jakarta, Gramedia. 